\title{
Dopamine receptor repertoire of human granulosa cells
} Veronica Rey-Ares ${ }^{1}$, Nikolai Lazarov$^{1}$, Dieter Berg${ }^{2}$, Ulrike Berg${ }^{2}$, Lars Kunz ${ }^{1}$
and Artur Mayerhofer*1

Address: ${ }^{1}$ Anatomisches Institut, Ludwig-Maximilians-Universität (LMU), München, Germany and ${ }^{2}$ Assisted Reproductive Technologies Bogenhausen, München, Germany

Email: Veronica Rey-Ares - v.rey@lrz.uni-muenchen.de; Nikolai Lazarov - nlazarov@medfac.acad.bg; Dieter Berg - IVF1BL@aol.com; Ulrike Berg - IVF1BL@aol.com; Lars Kunz - Lars.Kunz@Irz.uni-muenchen.de; Artur Mayerhofer* - mayerhofer@lrz.uni-muenchen.de

* Corresponding author

Published: 25 October 2007

Reproductive Biology and Endocrinology 2007, 5:40 doi:10.1 186/1477-7827-5-40

This article is available from: http://www.rbej.com/content/5/I/40

(C) 2007 Rey-Ares et al; licensee BioMed Central Ltd.

This is an Open Access article distributed under the terms of the Creative Commons Attribution License (http://creativecommons.org/licenses/by/2.0), which permits unrestricted use, distribution, and reproduction in any medium, provided the original work is properly cited.
Received: 6 July 2007

Accepted: 25 October 2007

\begin{abstract}
Background: High levels of dopamine (DA) were described in human ovary and recently evidence for DA receptors in granulosa and luteal cells has been provided, as well. However, neither the full repertoire of ovarian receptors for DA, nor their specific role, is established. Human granulosa cells (GCs) derived from women undergoing in vitro fertilization (IVF) are an adequate model for endocrine cells of the follicle and the corpus luteum and were therefore employed in an attempt to decipher their DA receptor repertoire and functionality.
\end{abstract}

Methods: Cells were obtained from patients undergoing IVF and examined using cDNA-array, RT-PCR, Western blotting and immunocytochemistry. In addition, calcium measurements (with FLUO-4) were employed. Expression of two DA receptors was also examined by in-situ hybridization in rat ovary. Effects of DA on cell viability and cell volume were studied by using an ATP assay and an electronic cell counter system.

Results: We found members of the two DA receptor families $\left(D_{1}-\right.$ and $D_{2}$-like) associated with different signaling pathways in human GCs, namely $D_{1}$ (as expected) and $D_{5}$ (both are Gs coupled and linked to cAMP increase) and $D_{2}, D_{4}\left(\mathrm{Gi} / \mathrm{Gq}\right.$ coupled and linked to IP3/DAG). $D_{3}$ was not found. The presence of the trophic hormone hCG $(10 \mathrm{lU} / \mathrm{ml})$ in the culture medium for several days did not alter mRNA (semiquantitative RT-PCR) or protein levels (immunocytochemistry/Western blotting) of $D_{1,2,4,5} D A$ receptors. Expression of prototype receptors for the two families, $D_{1}$ and $D_{2}$, was furthermore shown in rat granulosa and luteal cells by in situ hybridization. Among the DA receptors found in human GCs, $D_{2}$ expression was marked both at mRNA and protein levels and it was therefore further studied. Results of additional RT-PCR and Western blots showed two splice variants $\left(D_{2} L, D_{2} S\right)$. Irrespective of these variants, $D_{2}$ proved to be functional, as $D A$ raised intracellular calcium levels. This calcium mobilizing effect of DA was observed in the absence of extracellular calcium and was abolished by a $D_{2}$ blocker $(L-74 I, 626)$. DA treatment $(48 \mathrm{~h})$ of human GCs resulted in slightly, but significantly enlarged, viable cells.

Conclusion: $A$ previous study showed $D_{2}$ in human GCs, which are linked to cAMP, and the present study reveals the full spectrum of DA receptors present in these endocrine cells, which also includes $D_{2}$ like receptors, linked to calcium. Ovarian DA can act thus via $D_{1,2,4,5}$, which are co-expressed by endocrine cells of the follicle and the corpus luteum and are linked to different signaling pathways. This suggests a complex role of DA in the regulation of ovarian processes. 


\section{Background}

High levels of the catecholamine dopamine (DA) were described in human ovary $[1,2]$, raising questions about its role in the female gonad. Several possibilities have so far been suggested. It has been reported that monkey (Macaca mulatta) oocytes are able to take up DA and use it as precursor for the synthesis of noradrenaline (NE) [3], with the help of dopamine- $\beta$-hydroxylase (DBH), expressed by oocytes. NE may then be able to interact with ovarian alpha- and beta-receptors present on granulosa cells (GCs) of the follicle $[2,4,5]$. Furthermore, bovine luteal cells are reported to perform synthesis of NE in a similar way [6] and presumably this occurs also in intraovarian nerve fibers and neuron-like cells [7-9], which likewise express DBH. Thus, ovarian DA can be viewed as a precursor for NE in oocytes, endocrine cells and nerve cells and may have a plethora of functions (for example, steroid production and induction of follicle-stimulating hormone receptors) [9-11].

Nevertheless, recent publications have hinted to a yet different function. DA can, in general, act via its five different receptor subtypes $\left(D_{1}-D_{5}\right)$, which are organized in two families $\left(D_{1}\right.$-like $/ D_{2}$-like $)$ and one of them, $D_{1}$, has been described in human luteinizing GCs $[12,13]$ and more recently in endocrine cells of horse ovary [14]. In human GCs, isolated from preovulatory follicles of women undergoing in vitro fertilization (IVF) procedures, activation of $\mathrm{D}_{1}$ by selective agonists, as well as treatment with DA itself, did not affect progesterone synthesis [12]. $D_{1}$ activation was rather associated with cAMP elevations and increased phosphorylation of DARPP-32 (DA and CAMP regulated phospho-protein of MR 32,000), which is a down-stream third messenger of DA, but also with other signaling molecules in ovary and other tissues $[12,13,15-$ 18].

Whether other receptors for DA are present in ovary and on GCs and may thus provide a basis for its action, has as yet not been thoroughly examined. However a recent description of $\mathrm{D}_{2}$ in horse granulosa and luteal cells [14] prompted us to examine whether this and other DA receptors are also present in rat and human ovary. For functional studies we focused on human GCs.

\section{Methods}

\section{Human cells: GC preparation and culture}

Human GCs were obtained from follicular aspirates of women undergoing IVF, as described [12,13,19-21]. They were separated by centrifugation at $560 \times \mathrm{g}$ for $3 \mathrm{~min}$ and subsequent washing in serum-free DMEM/Ham's F-12 medium (1:1, Sigma, Deisenhofen, Germany). Washed cells were resuspended in culture medium supplemented with penicillin $(100 \mathrm{U} / \mathrm{ml})$, streptomycin $(100 \mu \mathrm{g} / \mathrm{ml})$, and $10 \%$ fetal calf serum as previously described [20]. The use of the cells for scientific experiments had been approved by the ethic's committee of the University of Munich (LMU), and written consent of the patients was obtained. For $\mathrm{Ca}^{2+}$ imaging and immunocytochemistry experiments, cells were cultured on glass cover slips, otherwise in plastic dishes or well plates in a humidified atmosphere with $5 \% \mathrm{CO}_{2}$ at $37^{\circ} \mathrm{C}$. Cells were used for the experiments described either on day 3 or day 4 after isolation. One group of cells was cultured with basal medium, which for the other group was supplemented with hCG (Sigma, $10 \mathrm{IU} / \mathrm{ml}$; from the $1^{\text {st }}$ day of culture).

\section{cDNA arrays}

Cells cultivated for 3 days were harvested and total RNA was prepared as previously described $[9,13,19,20]$ using RNEasy kit (Qiagen, Hilden, Germany). A total of $5 \mathrm{ng}$ was used for the GEArray Q Series Human Neuroscience1 Ion Channel \& Transporter Gene Array (SuperArray Bioscience Corporation, Biomol, Hamburg Germany), as described [20], following the instructions of the manufacturer. The array included $\mathrm{D}_{1}, \mathrm{D}_{2}, \mathrm{D}_{3}, \mathrm{D}_{5}$, but not $\mathrm{D}_{4}$, in quatriplicate spots. Negative controls consisted of puc18 plasmid cDNA. Chemiluminescence signals were recorded.

\section{RT-PCR}

Total RNA from several batches of cultured GCs (3 and 4 days after isolation) was prepared using RNEasy kit (Qiagen). As previously described $[12,22]$, total RNA (200$500 \mathrm{ng}$ ) was subjected to reverse transcription, using random primers (pdN6) and Superscript-RT II (Life Technologies, Karlsruhe, Germany). Commercial human brain cDNA (BD CLONTECH, Inc., Heidelberg, Germany) was used in addition.

Informations about the oligonucleotid primers for DA receptors used are summarized in Table 1. The primers for cyclophilin were identical to the ones described in [22]. As in human, two isoforms of the $\mathrm{D}_{2}$ are generated by alternative splicing of exon 6 of the pre-messenger RNA, changing the length of the third cytoplasmic loop involved in the coupling to $G$ proteins $[23,24]$. In order to be able to distinguish between these variants, we used a semi-nested, second PCR amplification approach. To be able to detect the long form, we employed a further antisense oligonucleotide primer complementary to the cDNA sequence of the $6^{\text {th }}$ exon present only in the long form (see Table 1: nested $D_{2}$ long: 5 '- ACT GGG AAA CTC CCA TT-3'). We used the antisense primer (see Table 1: nested $\mathrm{D}_{2}$ common: 5'-GAG CAT CTC CAT CTC CA-3') complementary to a common region of both receptor splice variants. With this approach a 261 bp product would correspond to the $\mathrm{D}_{2 \mathrm{~L}}$ and a $173 \mathrm{bp}$ product to the $\mathrm{D}_{2 \mathrm{~S}}$. 
Table I: Informations about oligonucleotide primers used for PCR amplification: Sense, antisense and antisense nested primer sequences, as well as their positions in the published $D_{1}-D_{5}$ sequences are provided.

\begin{tabular}{|c|c|c|}
\hline Human dopamine receptor $D_{1}$ & Sequence & Genebank accession number/location of primer \\
\hline & & NM 000794 \\
\hline sense & 5'-CTG AAG ACT CTG TCG GTG A-3' & $(1756-1774)$ \\
\hline antisense & 5'-ACT CAC CGT CTC TAT GGC A-3' & $(2031-2013)$ \\
\hline nested & 5'TGT AGC ATC CTA AGA GGG T-3' & $(1990-1972)$ \\
\hline Human dopamine receptor $D_{2}$ & & NM 000795 \\
\hline sense & 5'-TTC TAC GTG CCC TTC AT-3' & $(757-772)$ \\
\hline antisense & 5'-GGT CTG GAT CTC AAA GA-3' & $(1200-1184)$ \\
\hline nested $\mathrm{D}_{2}$ common & 5'-GAG CAT CTC CAT CTC CA-3' & $(1017-1000)$ \\
\hline nested $D_{2}$ long & 5'- ACT GGG AAA CTC CCA TT-3' & $(959-943)$ \\
\hline Human dopamine receptor $D_{3}$ & & NM 000796 \\
\hline sense & 5'-GGT ACT GGC CTT TGC TGT GTC C-3' & $905-926$ \\
\hline antisense & 5'-ATC CTT TTC CGT CTC CTT TGT TTC-3' & $1099-1076$ \\
\hline nested & 5'-CCA AAG GGC AGG TAG AAG GAC-3' & $1036-1016$ \\
\hline Human dopamine receptor $D_{4}$ & & NM 000797 \\
\hline sense & 5'-CCT TGC GGC TCC AAC TGT G-3' & $913-931$ \\
\hline antisense & 5'-AGC GCC TGC GTG ATG TGC-3' & $1112-1095$ \\
\hline nested & 5'-GAA GGC CCC GAC CAC CAC-3' & $1065-1048$ \\
\hline Human dopamine receptor $D_{5}$ & & NM 000798 \\
\hline sense & 5'-GGG CAG TTC GCT CTA TAC CAG-3' & $88-108$ \\
\hline antisense & 5'-CAG GAA AAG GTC TGA CAC GG-3' & $321-302$ \\
\hline nested & 5'-CAG AGA CAC GAT GAA GAC GTT-3' & $300-280$ \\
\hline
\end{tabular}

In order to be able to evaluate at least semiquantitatively possible changes after treatment of the cultures with hCG, or to take into account small loading differences, in all samples cyclophilin was co-amplified, as described before [22].

The PCR reaction products were separated on 2\% agarose gels and visualized with ethidium bromide. The identities of all PCR products were verified by direct sequencing using one of the specific primers [20].

\section{Measurements of intracellular $\mathrm{Ca}^{2+}$ concentrations}

$\mathrm{Ca}^{2+}$ measurements were performed on human GCs (day 3 or 4 ) cultured on glass cover slips, as described [21,25]. Two groups of cells were examined, namely cells kept without or treated with hCG $\left(10 \mathrm{IU} / \mathrm{ml}\right.$; since the $1^{\text {st }}$ day of culture). Briefly, the medium was replaced by fresh serum-free DMEM/Ham's F-12 medium containing $5 \mu \mathrm{M}$ fluo-4 AM (Molecular Probes, Eugene, OR, USA) and cells were loaded for $30 \mathrm{~min}$ at $37^{\circ} \mathrm{C}$ and $5 \% \mathrm{CO}_{2}$. Finally, cells were washed in extracellular solution $(140 \mathrm{mM} \mathrm{NaCl}, 3$ $\mathrm{mM} \mathrm{KCl}, 1 \mathrm{mM} \mathrm{CaCl}_{2}, 1 \mathrm{mM} \mathrm{MgCl}$, $10 \mathrm{mM}$ HEPES and $10 \mathrm{mM}$ glucose; $\mathrm{pH}$ 7.4) and were put into a recording chamber mounted on a TCS SP2 confocal microscope (Leica Microsystems, Bensheim, Germany). DA and carbachol (Sigma) were applied in $0.1 \mu \mathrm{M}$ and $100 \mu \mathrm{M}$, respectively. The $\mathrm{D}_{2}$ selective antagonist used was L741,626 (1 nM, Tocris Cookson Inc. Missouri, USA). Changes in fluorescence intensity were monitored for 10 min by sampling every $2 \mathrm{~s}$ at excitation and emission wavelengths of $488 \mathrm{~nm}$ and $520 \pm 20 \mathrm{~nm}$, respectively. The $\mathrm{Ca}^{2+}$ free experiments were done with extracellular solution without $\mathrm{Ca}^{2+}$ plus EGTA $(2 \mathrm{mM})$.

\section{Immunocytochemistry}

The cellular distribution of $\mathrm{D}_{1,2,4,5}$ proteins in cultured GCs was determined by immunocytochemistry using commercially available polyclonal antisera (rabbit anti$\mathrm{D}_{1}$ receptor, $\mathrm{R} \& \mathrm{D}$, Berkeley, CA, AS-3512G, 1:500; rabbit anti-D ${ }_{2}$, BioTrend Chemikalien Gmbh, Köln, Germany, AS-3526S, 1:500; rabbit anti- $D_{4}$; Chemicon International Inc., Temecula, CA, AB9422, 1:200; rabbit anti-D ${ }_{5}$ R\&D, Berkeley, CA, AS 3552G, 1:200). GCs were fixed on slides (Zamboni's fixative) and used directly after rinsing in 10 $\mathrm{mM}$ PBS ( $\mathrm{pH} 7.4$ ). Incubation with the antiserum was carried out overnight in a humidified chamber. A fluorescein isothiocyanate-labeled secondary goat anti-rabbit antiserum was used. For control purposes, the first antiserum was omitted, and incubations with normal rabbit serum were carried out instead. Sections were examined with a Zeiss Axiovert microscope (Zeiss, Oberkochen, Germany), equipped with a fluorescein filter set. 


\section{Western blot analyses}

Western blotting was performed as previously described $[12,13,18]$. In brief, GCs cultured with or without hCG (10 IU/ml for up to 4 days) were harvested, frozen, thawed, homogenized in $62.5 \mathrm{mM}$ Tris-HCl buffer $(\mathrm{pH}$ 6.8 ) containing $10 \%$ sucrose and $2 \%$ SDS, sonicated, and heated $\left(95^{\circ} \mathrm{C}\right.$ for $\left.5 \mathrm{~min}\right)$ in the presence of $10 \%$ mercaptoethanol. Samples (15 $\mu \mathrm{g} /$ lane) were separated electrophoretically on $10 \%$ or $12.5 \%$ SDS-polyacrylamide gels (SDS/PAGE). Proteins were transferred onto nitrocellulose membranes and probed with $\mathrm{D}_{1}$ and $\mathrm{D}_{2}$ antisera, as used for immunocytochemistry (1:1,000 dilution). Immunoreactivity was detected using peroxidase-labeled antisera (1:3,000, Dianova, Hamburg, Germany) and enhanced chemiluminescence, as described $[12,13,18]$ (Amersham Buchler, Braunschweig, Germany). In some cases, the blots were digitized, and integrated optical densities of the bands were determined using an edited version of the program NIH Image, as described previously $[12,13,18]$. To be able to detect small differences in loading, blots were also probed with mouse anti beta-actin antibody (Sigma). Three independent experiments were evaluated.

\section{Cell volume and viability}

To determine whether DA can affect cell viability or volume, cells were seeded in duplicate in 24-well tissue culture plates and stimulated for $48 \mathrm{~h}$ with or without DA $(10 \mu \mathrm{M})$. After that the cells were trypsinized and the average cell volume was examined using an electronic Coulter counter (CASY-TT, Schärfe System, Reutlingen, Germany).

To determine viability of cells in culture the CellTiter-Glo ${ }^{\circledR}$ Luminescent Cell Viability Assay (Promega) was used. Cells were seeded in triplicate in 48-well tissue culture plates and stimulated for $48 \mathrm{~h}$ with DA $(10 \mu \mathrm{M})$. The kit reagents were added directly to the cells in the well plate and luminescence of luciferase reaction, as a marker of cell viability, was measured with FLUOstar OPTIMA (BMG LABTECH GmbH, Offenburg/Germany).

\section{Rat tissues}

Ovaries from four adult, cycling Sprague-Dawley rats (Charles River, Sulzfeld Germany) [26] were quickly removed and processed as described previously [26]. The phases of the estrus cycles were not recorded. All methods unless specified, were previously described in detail $[3,9,12,13,27,28]$.

\section{In situ hybridization (ISH)}

The ISH procedures were performed as described previously $[26,28,29]$. Briefly, cryostat sections of ovaries were probed with a digoxigenin-uridine triphosphate labeled cRNA antisense or for control purposes, with sense probes. Templates for generation of riboprobes were par- tial RT-PCR derived cDNAs: rat $D_{2}$ (291 bp partial cDNA subcloned in pGEM3Z; corresponding to position 16021893; see [30], Genbank accession NM 012547) and rat $\mathrm{D}_{1}$ (396 bp in pSP72, corresponding to 484-880; see [31], Genbank accession M35077). These templates were a gift from S. Ojeda to A. Mayerhofer. Riboprobes were transcribed with T7 RNA polymerase (Promega) or with SP6 RNA polymerase (Promega). Experiments were performed using sections of 4 individual rat ovaries.

\section{Statistics}

Data are expressed as mean + SEM unless indicated otherwise in the text and graphs. Statistical significance of changes was determined using ANOVA and NewmanKeuls's post test ( $\mathrm{Ca}^{2+}$ measurements) and by paired Student's t-test (comparison of cell volumes and ATP assay), performed with GraphPad Prism version 4.0a for Macintosh (GraphPad Software, San Diego California USA). Statistical significance was accepted for $\mathrm{p}<0.05$.

\section{Results}

\section{Evidence for $D_{1,2,4,5}$ expression in human $G C_{s}$}

We tested which DA receptors are present in human GCs, i.e. a cell type derived from large preovulatory follicles, which are in the process of differentiation into luteal cells (Fig. 1, 2, 3).

RT-PCR experiments performed with mRNA obtained from GCs on the 3rd or 4th day of culture yielded cDNAs of expected sizes (Fig. 1), which upon sequencing proved to be identical to the known human D1,2,4,5 sequences.

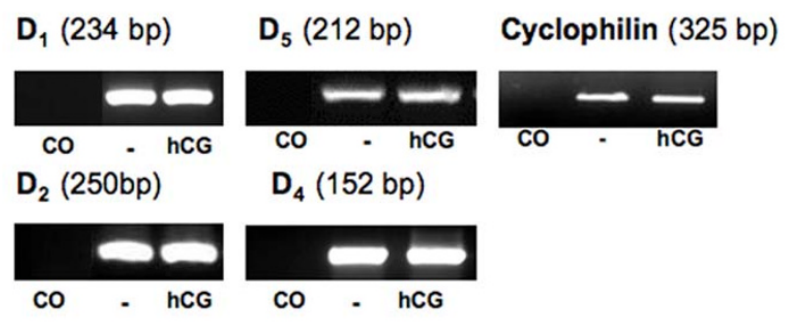

\section{Figure I}

Gene expression of $D A$ receptors $D_{1,2,4,5}$ in human GCs. Ethidium bromide-stained agarose gel showing RTPCR products, which correspond to expected size of $D_{1,2,4,5}$ cDNAs in GCs (day 3 and day 4 of culture, with and without hCG stimulation). After sequencing they proved to be identical to the human $D_{1,2,4,5}$. Results of PCR amplification were not visibly different between cells treated with or without hCG, as judged from similar bands and similar levels of cyclophilin, which was also amplified. Control (CO) was without input mRNA in RT-PCR reactions. The gel shows results obtained from one of four experiments that yielded comparable results. 

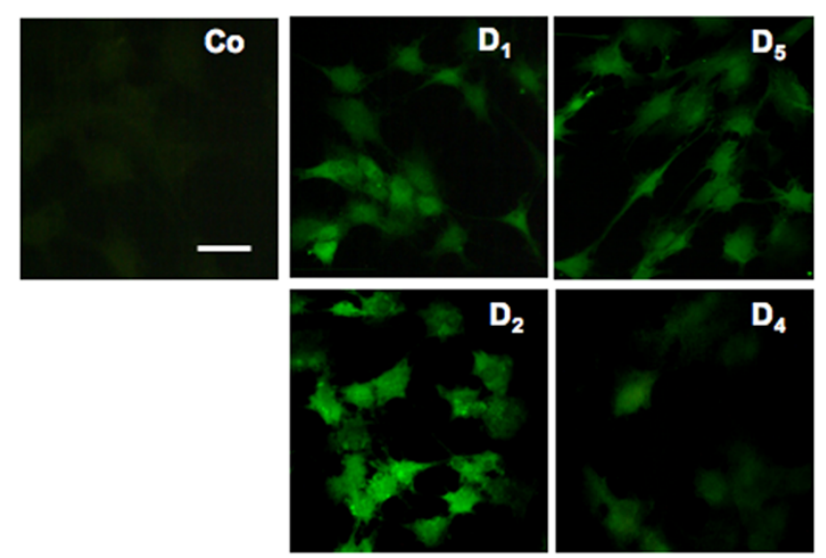

\section{Figure 2}

$D_{1,2,4,5}$ protein detection in human GCs. Immunofluorescence localization of the $D_{1,2,4,5}$ proteins in cultured GCs (day 3 after isolation). Control (Co), omission of antisera. Bar is equivalent to $40 \mu \mathrm{m}$; antisera dilutions I:500.

Experiments using specific primers for D3 did not yield results. The presence of hCG in the medium did not alter levels of DA receptor D1,2,4,5 mRNAs, as judged from semiquantitative RT-PCR experiments when cyclophilin was used for normalization (Fig. 1).

Results of gene array experiments provided evidence for the presence of $D_{1,2,5}\left(D_{4}\right.$ was not represented on the array membrane; $D_{3}$ was found to be not expressed; data not shown except for $\mathrm{D}_{2}$, see Fig. $3 \mathrm{~A}$ ).

By immunocytochemistry $D_{1,2,4,5}$ receptors proteins were also demonstrated in virtually all GCs using specific $D_{1,2,4,5}$ receptor antisera. $D_{1,2,4,5}$ immunoreactivities were associated mainly with the cytoplasm of all GCs, and all controls performed were negative (Fig. 2). $\mathrm{D}_{2}$ immunoreactivity appeared to be strongest.

\section{$D_{2}$ receptor splice variant}

For the human $\mathrm{D}_{2}$ we found evidence of the long splice variant, $\mathrm{D}_{2 \mathrm{~L}}$, and also the short form was obtained using semi-nested second PCR steps, albeit the presence of this splice variant was inconsistent and appeared not to be associated with treatment or time in culture (Fig. 3B). Both splice variants were found also at the protein level by Western blot (Fig. 3C).

\section{Evidence for $D_{1,2}$ receptor gene expression in rat ovary} In situ hybridization revealed that $\mathrm{D}_{1}$ and $\mathrm{D}_{2}$ mRNAs are present in rat ovarian endocrine cells. Signals were detectable only when antisense cRNA was used, but not in sense cRNA controls. Signals were associated with GCs of folli-
A)

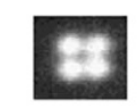

B)

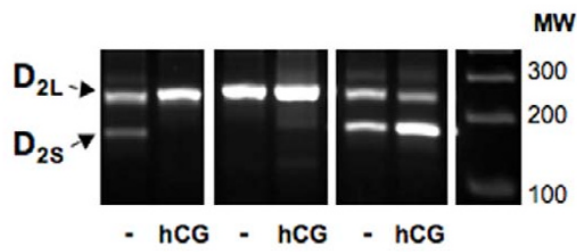

C)

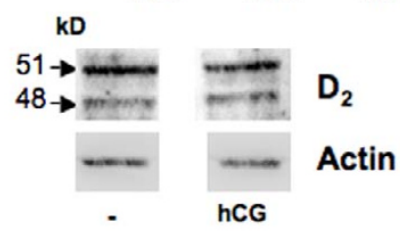

Figure 3

$\mathbf{D}_{2}$ in human GCs. A) Result of cDNA array, showing evidence for expression of $D_{2}$. B) Ethidium bromide-stained agarose gel showing RT-PCR products which identify $D_{2 L}$ (26I bp) and D2S (I73 bp). Note that $D_{2 L}$ is consistently expressed, while $D_{2 S}$ expression is not depending on age or treatment with hCG (day 4 of culture, $n=4 /$ each). C) Western blot analysis of $D_{2}$ in cultured human GCs. Cells were treated without or with hCG for 4 days and I $5 \mu \mathrm{g}$ of total protein was analyzed. Note that the treatment has no effect on the overall levels of $D_{2}$ protein, which can be readily detected as a double band of about 48 and $5 \mathrm{l}$ kDa, representing $D_{2 S}$ and $D_{2 L}$, respectively. Subsequent detection of beta actin in the same blots was also performed to normalize the density of the bands. Data shown are from one of three independent experiments yielding similar results.

cles, but were stronger in theca and interstitial cells and the corpus luteum (Fig. 4).

\section{Elucidation of $D_{2}$ receptor functionality in human $G C s$} Changes of intracellular $\mathrm{Ca}^{2+}$ levels in human GCs

The functionality of $\mathrm{D}_{2}$ (both $\mathrm{S}$ and $\mathrm{L}$ splice forms) is linked to intracellular $\mathrm{Ca}^{2+}$ levels, which we thus monitored in human GCs. The addition of DA $(0.1 \mu \mathrm{M})$ rapidly increased intracellular $\mathrm{Ca}^{2+}$ levels (Fig. 5A). The number of the cells responsive to DA was lower than in the positive control, used for methodological comparison, namely the acetylcholine analogue carbachol [21].

Furthermore, the specificity of the DA action was shown by using the $\mathrm{D}_{2}$ blocker L-741,626 (1 nM), which prevented the $\mathrm{Ca}^{2}+$ increases (Fig. 5B; $\mathrm{n}=7$ experiments with 60-90 cells each). The response was not depending on the presence of extracellular $\mathrm{Ca}^{2+}$ in the medium, indicating 

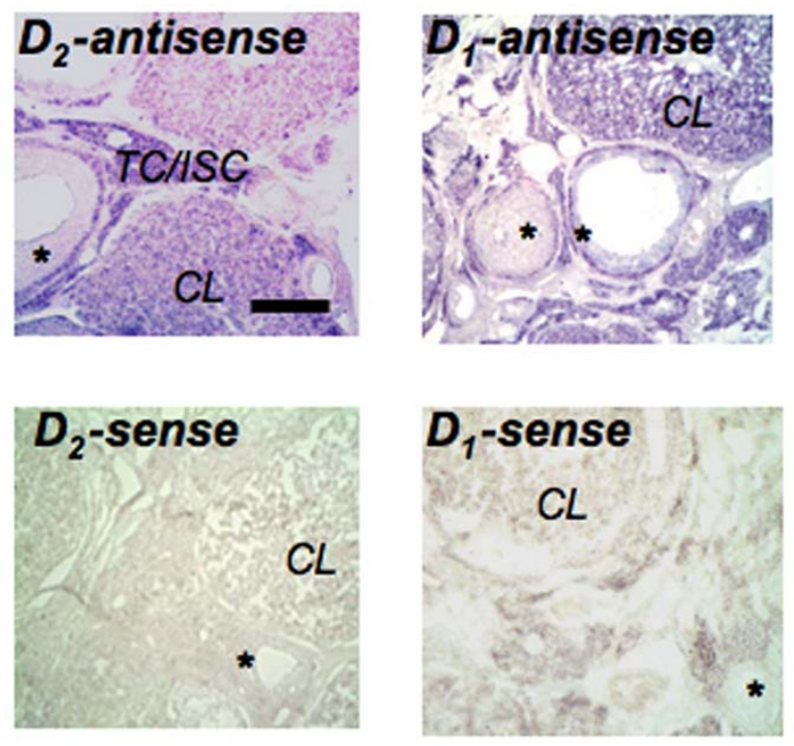

\section{Figure 4}

In situ hybridization - rat ovary. Non-radioactive in situ hybridization experiments of rat ovarian slices with $D_{1}$ or $D_{2}$ antisense cRNA show strongest signals in theca and interstitial cells (TC/ISC) and the corpus luteum (CL), while follicular GCs (asterisk) reveal only a moderate signal. All signals are absent from a $D_{1}$ and $D_{2}$ receptor sense control. Bar: approximately $100 \mu \mathrm{m}$.

release from intracellular sites (data not shown, $\mathrm{n}=4$ experiments with 20-50 cells each).

Interestingly, the numbers of cells responsive to DA by intracellular $\mathrm{Ca}^{2+}$ elevations were significantly $(\mathrm{p}<0.05)$ higher when GCs were cultured in the presence of hCG, as compared to untreated cultures. The percentage of responding GCs to DA without hCG stimulation was $10.2 \%$ and $3.7 \%$ on the $3^{\text {rd }}$ and on the $4^{\text {th }}$ day of culture, respectively. After hCG exposure the percent of reacting cells was $24 \%$ and $21 \%$ on day 3 and 4 , respectively, indicating a role of hCG in promoting $\mathrm{D}_{2}$ functionality (Fig. 5C).

\section{Effects of DA on cell viability and volume of human GCs} Human GCs exposed to DA $(10 \mu \mathrm{M})$ for 48 h significantly increased the cell volume (Fig. 6A; control: $8085 \pm 906$ femto liters (fl); DA $10 \mu \mathrm{M}$ : $10389 \pm 1053 \mathrm{fl} ; \mathrm{n}=4, \mathrm{p}<$ 0.05 ; determined with CASY-TT). Furthermore, the luciferase ATP assay showed a significant increased signal when the GCs were stimulated for $48 \mathrm{~h}$ with DA (Fig. 6B; control: $100 \%$; DA $10 \mu \mathrm{M}$ : $108.7 \pm 0.7 \%$; $=3, \mathrm{p}<0.05$ ). In this assay the signal is proportional to the amount of ATP present, which correlates with the number of viable cells and/or their size. Concomitant increases in cellular volume and in ATP levels imply that the average sizes of viable cells is increased after treatment with DA. Coexpression of multiple DA receptors on each cell and lack of specific tools to distinguish between the different DA receptor members in primary cells, kept us from further investigations.

\section{Discussion}

Catecholamines, especially NE, have long been implicated in the control of ovarian function [1-9], but whether the catecholamine DA has a specific function within the ovary is not known. A prerequisite for such an action is the presence of functional receptors in the ovary. Our results show that most of the DA receptors are present in human GCs and that two members of each DA receptor family linked to different signaling pathways are co-expressed. Our results also show expression of two prototype DA receptor family members $\left(D_{1} / D_{2}\right)$ in rat ovarian endocrine cells. This resembles the previously shown expression in horse ovary and extend our studies in human and monkey ovary [14].

For our studies we employed cultured human GCs, which stem from the preovulatory follicle and are undergoing luteinization. These like monkey granulosa and luteal cells, express $D_{1}[12,13]$ and as we found also $D_{5}$. A previous study has shown that this receptor is linked to CAMP and DARPP-32 phosphorylation $[12,13] . \mathrm{D}_{1}$ and $\mathrm{D}_{5}$ together are known also as the $\mathrm{D}_{1}$-like subfamily of DA receptors, which is linked to Gs and to a similar signaling pathway. It is possible that due to co-expression of $D_{1} / D_{5}$, which we have now observed, parts of the effects ascribed previously to $\mathrm{D}_{1}$ are actually due to (co)-activation of both receptors. The agonists/antagonist available in the concentrations we can use in our model, does not allow to distinguish between these subtypes or draw further conclusions [32-34].

The other $\mathrm{D}_{2}$-like subfamily of DA receptors consists of $\mathrm{D}_{2,3,4}$, of which two were found in human GCs, as well. $\mathrm{D}_{2}$ appeared to be strongly expressed, as judged from our results using a gene array, as well as immunocytochemistry and Western blotting. This subtype is also expressed in horse ovarian endocrine cells [14] and in rat follicles and corpus luteum (this study). We therefore chose to investigate this receptor subtype further.

That $\mathrm{D}_{2}$ mRNA can be alternatively spliced became evident in our study, as well. Evidence for constant expression of the long form splice variant $\left(\mathrm{D}_{2 \mathrm{~L}}\right)$ was obtained, while the short form $\left(\mathrm{D}_{2 S}\right)$ was found in an inconsistent manner and appeared not to be associated with time in culture. The antiserum used for both immunocytochemistry and Western blot detects both forms and either experiment indicated ubiquitous presence and high levels in all 

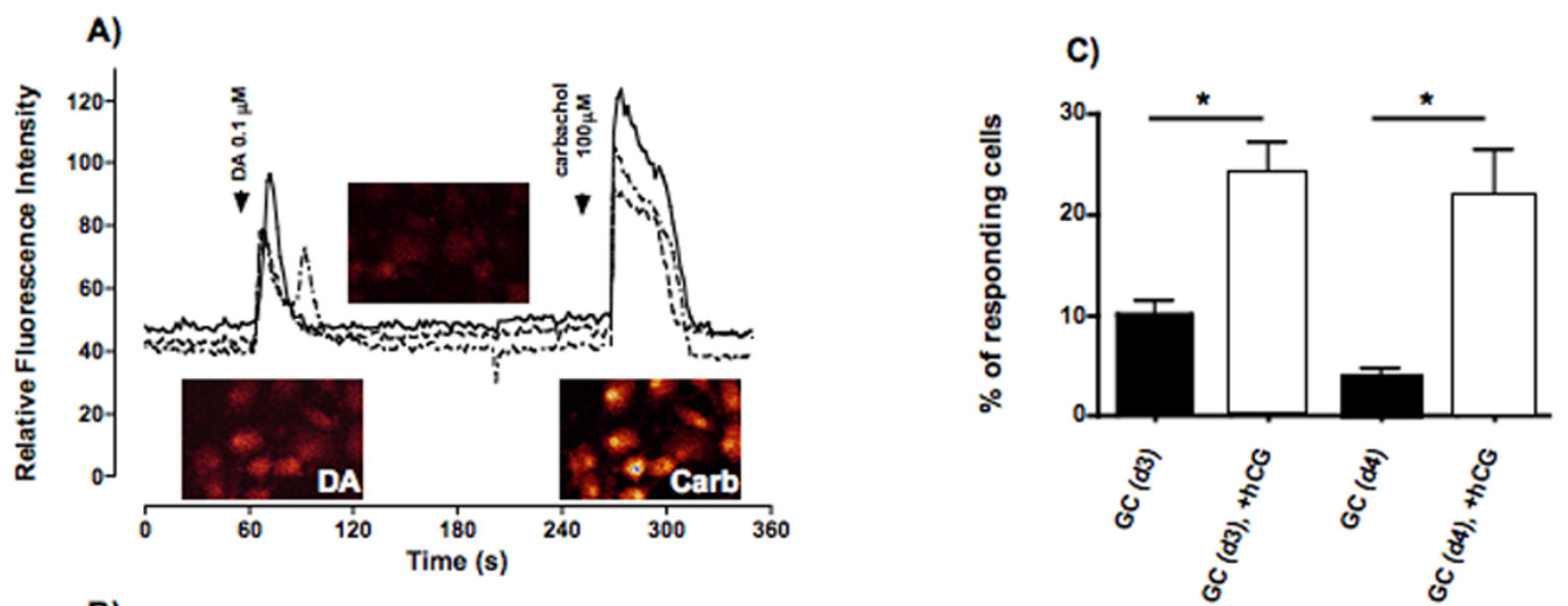

B)

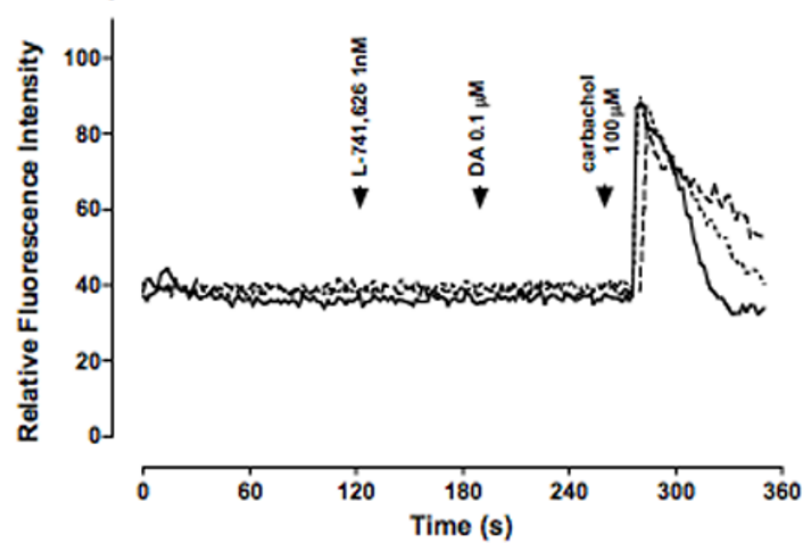

Figure 5

Measurements of intracellular $\mathbf{C a}^{2+}$ concentrations in human GCs. A) Line plot graphic showing the time-course of intracellular $\mathrm{Ca}^{2+}$ changes for three representative cells sequentially treated with buffer (at $\mathrm{t}=0$ ), $0.1 \mu \mathrm{M} \mathrm{DA}$, and I00 $\mu \mathrm{M}$ carbachol. Color images of fluo-4 AM loaded GCs of identical viewing areas are also provided. Color changes from red/yellow to yellow/blue represent increased intracellular $\mathrm{Ca}^{2+}$ levels. B) Line plot graphic showing the time-course of intracellular $\mathrm{Ca}^{2+}$ changes for three representative cells sequentially treated with buffer $(\mathrm{t}=0), \mathrm{I} \mathrm{nM} \mathrm{L}-74 \mathrm{I}, 626,0 . \mathrm{I} \mu \mathrm{M} \mathrm{DA}$, and I00 $\mu$ M carbachol, as a positive control. Data are expressed as relative fluorescence intensities corresponding to a pseudo color scale from red/yellow to yellow/blue. Experiments were repeated seven times with a total of 60 to 90 cells each examined in detail. C) Percentage of GCs responding to DA with increased intracellular $\mathrm{Ca}^{2+}$ levels. The graphic represents the percentage of $\mathrm{GCs}$ (day 3 or 4 of culture) responding to DA $(0.1 \mu \mathrm{M})$ with an increase in the intracellular $\mathrm{Ca}^{2+}$ levels. GCs were either untreated or stimulated with hCG $(10 \mathrm{lU} / \mathrm{ml})$ since the $\mathrm{I}^{\text {st }}$ day of culture. Experiments were repeated seven times with a total of 60 to 90 cells each examined in detail. Data represent means + SEM (ANOVA/post-test $\left.*_{p}<0.05\right)$.

cultured GCs. Effects of hCG on mRNA and protein levels of this subtype or on possibly splice variants were also not obvious with the experimental approach chosen, and no changes were observed with regard to the expression of the other DA receptors in GCs, as well.

It is well established that action of DA on either splice variant of the $\mathrm{D}_{2}$ is linked to a phosphatidylinositol-linked mobilization of intracellular $\mathrm{Ca}^{2+}$ [35]. Although all cells appeared to express the receptor protein, we found when we measured the $\mathrm{Ca}^{2+}$ response of individual cells to DA that only a percentage of the cultured cells showed indeed the expected changes. Furthermore, although we did not detect changes in overall levels of $\mathrm{D}_{2}$ in the presence of hCG in the culture medium, the percentage of responding GCs was significantly higher under these circumstances as compared to untreated cultures. The dependency on culture time or the presence of hCG indicate a relationship of the cellular differentiation state to $\mathrm{D}_{2}$ function and a role of the trophic hormone hCG/LH in promoting $\mathrm{D}_{2}$ functionality. Detailed insights e.g. at what level this may occur, are currently not possible and it remains, likewise, 


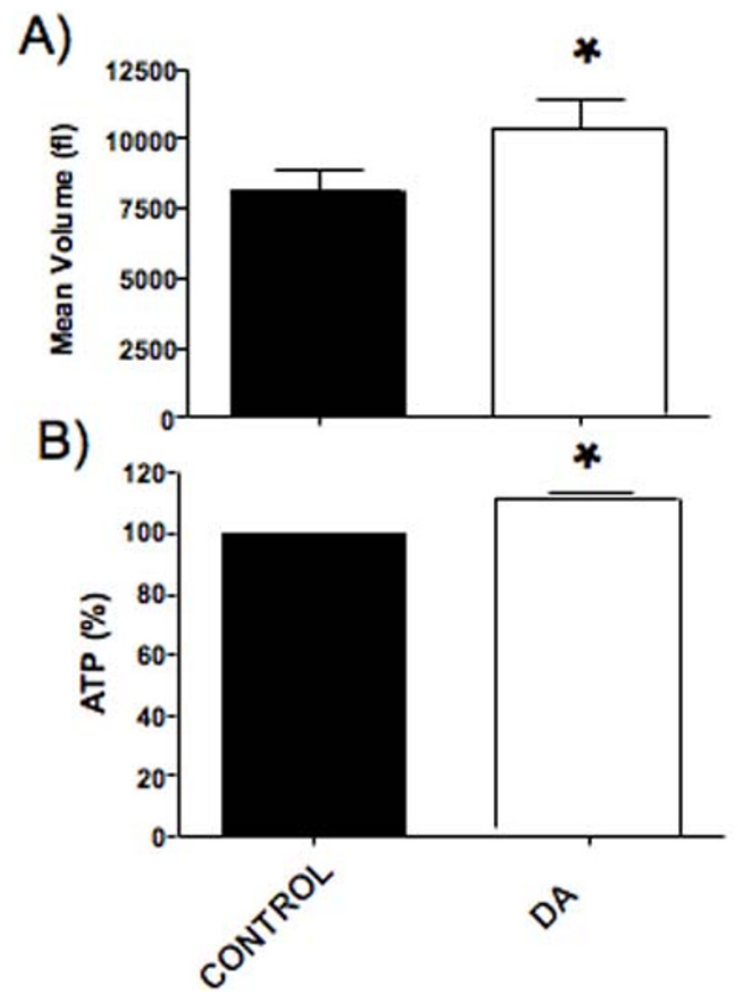

Figure 6

Effect of DA on mean cellular volume and viability. $A)$ DA $(10 \mu M)$ significantly $(p<0.05)$ increased the cellular volumes of GCs (means + SEM of 4 experiments; $48 \mathrm{~h}$ ). B) The treatment of human GCs with DA $(10 \mu \mathrm{M} ; 48 \mathrm{~h})$ resulted in significantly increased ATP levels $(p<0.05$; means + SEM of 3 experiments).

to be investigated whether possible transactivation of the $\mathrm{D}_{2}$, e.g. by EGF receptor [36] or other as yet unknown interactions may be involved.

In human the two splice variants, $\mathrm{D}_{2 \mathrm{~S}}$ and $\mathrm{D}_{2 \mathrm{~L}^{\prime}}$ exhibit differences in the length of the third cytoplasmic loop involved in the coupling to G proteins $[23,24]$ and intracellular signaling $[37,38]$ other than phosphatidylinositollinked mobilization of intracellular $\mathrm{Ca}^{2+}$. For example in neurons, $\mathrm{D}_{2 \mathrm{~L}}$ which is constantly present in human GCs, is in general also associated with inhibition of cAMP synthesis, stimulation of the MAP kinase pathway, activation of $\mathrm{G}$ protein coupled inwardly rectifying potassium channels (GIRKs), inhibition of $\mathrm{Ca}^{2+}$ channels, potentiation of arachidonic acid release and increased $\mathrm{Na}^{+} / \mathrm{K}^{+}$-ATPase activity $[39,40]$. In the present report on this subject we were not able to address the full plethora of possible actions, but focused on effects of DA to mobilize $\mathrm{Ca}^{2+}$, which, by use of a specific $\mathrm{D}_{2}$ antagonist, were clearly shown. The $\mathrm{Ca}^{2+}$ mobilizing effect of DA was not dependent on the presence of extracellular $\mathrm{Ca}^{2+}$, i.e. it did most likely not involve opening of $\mathrm{Ca}^{2+}$ channels in the plasma membrane.

To summarize, human GCs possess four of the five known DA receptors, one of which exists in two possible splice variants and co-expression of these receptors is likely. Possible interactions of these DA receptors for example at the intracellular level (including DARPP-32) are to be assumed. Unfortunately the pharmacological tools available for the study of DA receptors in primary human GCs are limited [32-34], and antagonists/agonists interact often in a concentration-dependent manner with several receptors. Other approaches including siRNA are not readily possible for these primary cells. Clearly, the study of such interactions would be of great interest, for example with regard to DARPP-32, previously detected in human GCs and ovarian endocrine cells [12,13,18] or recently also in other endocrine tissue [41].

Therefore, a complete answer to the naive question about a specific role of DA in the ovary, which we posed, can not be given and may turn out to be much more complex than anticipated. Yet, a partial answer is provided by the results of the present study. By showing that four of the five known DA receptors are present in endocrine ovarian cells, they clearly indicate that DA is more than a precursor of NE (see Introduction). Ovarian endocrine cells are thus newly identified targets of ovarian DA and we assume based on our current results complex interactions between different DA receptor signaling cascades. Our study only provides first hints to an outcome of such actions, which implies a "trophic" role of DA for these cells. We found that treatment of cultured cells for up to $48 \mathrm{~h}$ with DA increased their size and viability, suggesting that DA may serve as a "differentiation factor". In brain, trophic actions of neurotransmitter are established $[42,43]$. Insights into actions of yet another prototype neurotransmitter present in ovary, namely acetylcholine, which stimulates GCs proliferation and differentiation, supports the notions that neurotransmitters may act as local growth factors outside the brain $[44,45]$.

A role for ovarian DA is likely not restricted to GCs or endocrine cells, as other ovarian cells (e.g. oocytes, [46] or others) may have DA receptors or DA transporters, as well. It remains also to be investigated, whether ovarian microvasculature cells as reported in other tissues are affected by DA, which could be a profound modulator of VEGF actions and angiogenesis [46].

The presence of high ovarian DA levels on one side [1,47] and of functional DA receptors on ovarian endocrine cells 
linked to different second messenger pathways, on the other side, imply as yet unknown ovarian signaling systems and specific roles of DA also in the human ovary. Furthermore, existence of the DA transporter and DBH in oocytes [3] or luteal cells [3], indicate actions of DA as a precursor for NE, within the ovary.

Taken together, these results may be of as yet unforeseeable relevance to human ovarian function. This assumption is based for example on the interaction of many drugs [37] with components of the DA and the NE system, including haloperidol, cocaine and others, which may be able to affect the ovary directly. It also remains to be studied, whether like in brain, DA and steroid hormone signaling may converge, a possibility shown for DA and progesterone [48]. Finally, at least in animal studies, catecholamines (mainly NE) have been implicated in polycystic ovarian syndrome (PCOS; see [47]). Whether NE and specifically the catecholamine DA and ovarian DA receptors are involved in human PCOS, a common cause of infertility in women, remains to be studied. Our pilot studies indicate that in GCs from PCOS patients DA receptors are expressed (unpublished).

\section{Conclusion}

The present study shows that DA receptors are expressed by rat ovarian endocrine cells. Human GCs possess four of the five known DA receptors, one of which exists in two possible splice variants, and co-expression of these receptors is likely. Our results provide a basis for future studies addressing the role of these receptors for the ovary in health and disease.

\section{Competing interests}

The author(s) declare that they have no competing interests.

\section{Authors' contributions}

VR-A performed most of the cellular and molecular experiments, contributed to the analysis and interpretation of data and to the drafting of the manuscript. NL performed in situ hybridization experiments and was involved in writing of the paper. DB and UB provided human GCs, were involved in the study design and contributed to the writing of the manuscript. LK was involved in conception of the study, $\mathrm{Ca}^{2+}$ measurements, statistical analysis of data and writing of the paper. AM conceived of the study, coordinated most of the experiments, was involved in analysis and interpretation of the data and the writing of the paper. All authors read and approved the final manuscript.

\section{Acknowledgements}

We thank Annette Krieger, Christine Mayer, Romi Rämsch, Christine Roggors, Astrid Tiefenbacher and Barbara Zschiesche for technical assistance. The gift of $D_{1}$ and $D_{2}$ receptor $c D N A$ from Sergio Ojeda, ONPRC-OHSU,
Beaverton, Oregon to AM is gratefully acknowledged. NL was supported by the Alexander von Humboldt Foundation through the resumption of a fellowship (Grant I015945). This study was supported in major parts by DFG Mal080/I7-I (to AM).

\section{References}

I. Bodis J, Bognar Z, Hartmann G, Torok A, Csaba IF: Measurement of noradrenaline, dopamine and serotonin contents in follicular fluid of human graafian follicles after superovulation treatment. Gynecol Obstet Invest 1992, 33(3): 165-167.

2. Lara HE, Porcile A, Espinoza J, Romero C, Luza SM, Fuhrer J, Miranda C, Roblero L: Release of norepinephrine from human ovary: coupling to steroidogenic response. Endocrine 2001, I5(2): 187-192.

3. Mayerhofer A, Smith GD, Danilchik M, Levine JE, Wolf DP, Dissen GA, Ojeda SR: Oocytes are a source of catecholamines in the primate ovary: evidence for a cell-cell regulatory loop. Proc Natl Acad Sci USA 1998, 95( I 8): I0990-10995.

4. Fohr KJ, Mayerhofer A, Sterzik K, Rudolf M, Rosenbusch B, Gratzl M: Concerted action of human chorionic gonadotropin and norepinephrine on intracellular-free calcium in human granulosa-lutein cells: evidence for the presence of a functional alpha-adrenergic receptor. J Clin Endocrinol Metab 1993, 76(2):367-373.

5. Young FM, Menadue MF, Lavranos TC: Effects of the insecticide amitraz, an alpha2-adrenergic receptor agonist, on human luteinized granulosa cells. Hum Reprod 2005, 20(I I):3018-3025.

6. Kotwica J, Bogacki M, Rekawiecki R: Neural regulation of the bovine corpus luteum. Domest Anim Endocrinol 2002, 23(I2):299-308.

7. D'Albora H, Anesetti G, Lombide P, Dees WL, Ojeda SR: Intrinsic neurons in the mammalian ovary. Microsc Res Tech 2002, 59(6):484-489.

8. Dees WL, Hiney JK, Schultea TD, Mayerhofer A, Danilchik M, Dissen GA, Ojeda SR: The primate ovary contains a population of catecholaminergic neuron-like cells expressing nerve growth factor receptors. Endocrinology 1995, I36(1 2):5760-5768.

9. Mayerhofer A, Dissen GA, Costa ME, Ojeda SR: A role for neurotransmitters in early follicular development: induction of functional follicle-stimulating hormone receptors in newly formed follicles of the rat ovary. Endocrinology 1997, I 38(8):3320-3329.

10. Oikawa $M$, Hsueh $A$ ): Beta-adrenergic agents stimulate tissue plasminogen activator activity and messenger ribonucleic acid levels in cultured rat granulosa cells. Endocrinology 1989 , I 25(5):2550-2557.

II. Wiesak T, Przala J, Muszynska A, Hunter MG: Effect of catecholamines and FSH on progesterone secretion by pig granulosa cells. Endocrinol Exp 1990, 24(4):449-456.

12. Mayerhofer A, Fritz S, Grunert R, Sanders SL, Duffy DM, Ojeda SR, Stouffer RL: DI-Receptor, DARPP-32, and PP-I in the primate corpus luteum and luteinized granulosa cells: evidence for phosphorylation of DARPP-32 by dopamine and human chorionic gonadotropin. J Clin Endocrinol Metab 2000, 85( I 2):4750-4757.

13. Mayerhofer A, Hemmings HC Jr, Snyder GL, Greengard P, Boddien S, Berg U, Brucker C: Functional dopamine-I receptors and DARPP-32 are expressed in human ovary and granulosa luteal cells in vitro. J Clin Endocrinol Metab 1999, 84(I):257-264.

14. King SS, Campbell AG, Dille EA, Roser JF, Murphy LL, Jones KL: Dopamine receptors in equine ovarian tissues. Domest Anim Endocrinol 2005, 28(4):405-4I5.

15. Fienberg AA, Hiroi N, Mermelstein PG, Song W, Snyder GL, Nishi A, Cheramy A, O'Callaghan JP, Miller DB, Cole DG, Corbett R, Haile CN, Cooper DC, Onn SP, Grace AA, Ouimet CC, White FJ, Hyman SE, Surmeier DJ, Girault J, Nestler EJ, Greengard P: DARPP-32: regulator of the efficacy of dopaminergic neurotransmission. Science 1998, 28 I (5378):838-842.

16. Greengard P: The neurobiology of slow synaptic transmission. Science 200I, 294(5544): I024-I030.

17. Greengard P, Allen PB, Nairn AC: Beyond the dopamine receptor: the DARPP-32/protein phosphatase-I cascade. Neuron 1999, 23(3):435-447.

18. Mayerhofer A, Fritz S, Mani S, Rajendra Kumar T, Thalhammer A, Ingrassia $P$, Fienberg AA, Greengard P: Ovarian function and mor- 
phology after deletion of the DARPP-32 gene in mice. Exp Clin Endocrinol Diabetes 2004, I I 2(8):45I-457.

19. Fritz S, Kunz L, Dimitrijevic N, Grunert R, Heiss C, Mayerhofer A: Muscarinic receptors in human luteinized granulosa cells: activation blocks gap junctions and induces the transcription factor early growth response factor-I. J Clin Endocrinol Metab 2002, 87(3): I 362-| 367.

20. Kunz L, Ramsch R, Krieger A, Young KA, Dissen GA, Stouffer RL, Ojeda SR, Mayerhofer A: Voltage-dependent K+ channel acts as sex steroid sensor in endocrine cells of the human ovary. Cell Physiol 2006, 206(1):167-174.

21. Mayerhofer A, Föhr KJ, Sterzik K, Gratzl M: Carbachol increases intracellular free calcium concentrations in human granulosa-lutein cells. J Endocrinol 1992, I35(I): 153-159.

22. Frungieri MB, Albrecht M, Raemsch R, Mayerhofer A: The action of the mast cell product tryptase on cyclooxygenase-2 (COX2) and subsequent fibroblast proliferation involves activation of the extracellular signalregulated kinase isoforms I and 2 (erk I/2). Cell Signal 2005, I7(4):525-533.

23. Dal Toso R, Sommer B, Ewert M, Herb A, Pritchett DB, Bach A, Shivers BD, Seeburg PH: The dopamine D2 receptor: two molecular forms generated by alternative splicing. Embo J 1989 8(13):4025-4034

24. Grandy DK, Marchionni MA, Makam H, Stofko RE, Alfano M, Frothingham L, Fischer JB, Burke-Howie KJ, Bunzow JR, Server AC, Civelli $\mathrm{O}$ : Cloning of the cDNA and gene for a human D2 dopamine receptor. Proc Natl Acad Sci USA 1989, 86(24):9762-9766.

25. Albrecht M, Frungieri MB, Kunz L, Ramsch R, Meineke V, Kohn FM Mayerhofer A: Divergent effects of the major mast cell products histamine, tryptase and TNF-alpha on human fibroblast behaviour. Cell Mol Life Sci 2005, 62(23):2867-2876.

26. Lazarov NE, Schmidt U, Wanner I, Pilgrim C: Mapping of DI dopamine receptor mRNA by non-radioactive in situ hybridization. Histochem Cell Biol 1998, 109(3):27I-279.

27. Mayerhofer A, Dissen GA, Parrott JA, Hill DF, Mayerhofer D, Garfield RE, Costa ME, Skinner MK, Ojeda SR: Involvement of nerve growth factor in the ovulatory cascade: trkA receptor activation inhibits gap junctional communication between thecal cells. Endocrinology 1996, I 37( I 2):5662-5670.

28. Sommersberg B, Bulling A, Salzer U, Frohlich U, Garfield RE, Amster$\operatorname{dam} A$, Mayerhofer A: Gap junction communication and connexin 43 gene expression in a rat granulosa cell line: regulation by follicle-stimulating hormone. Biol Reprod 2000, 63(6): $1661-1668$.

29. Lazarov N, Pilgrim C: Localization of DI and D2 dopamine receptors in the rat mesencephalic trigeminal nucleus by immunocytochemistry and in situ hybridization. Neurosci Lett 1997, 236(2):83-86.

30. Bunzow JR, Van Tol HH, Grandy DK, Albert P, Salon J, Christie M, Machida CA, Neve KA, Civelli O: Cloning and expression of a rat D2 dopamine receptor cDNA. Nature 1988 336(620I):783-787.

31. Monsma FJ Jr, Mahan LC, McVittie LD, Gerfen CR, Sibley DR: Molecular cloning and expression of a DI dopamine receptor linked to adenylyl cyclase activation. Proc Natl Acad Sci USA 1990, 87(17):6723-6727.

32. Kulagowski J], Broughton HB, Curtis NR, Mawer IM, Ridgill MP, Baker R, Emms F, Freedman SB, Marwood R, Patel S, Patel S, Ragan Cl, Leeson PD: 3-((4-(4-Chlorophenyl)piperazin-I-yl)-methyl)-I Hpyrrolo-2,3-b-pyridine: an antagonist with high affinity and selectivity for the human dopamine D4 receptor. J Med Chem 1996, 39(10): 1941-1942.

33. Millan MJ, Lejeune F, Gobert A, Brocco M, Auclair A, Bosc C, Rivet JM, Lacoste JM, Cordi A, Dekeyne A: S186I6, a highly potent spiroimidazoline agonist at alpha(2)-adrenoceptors: II. Influence on monoaminergic transmission, motor function, and anxiety in comparison with dexmedetomidine and clonidine. J Pharmacol Exp Ther 2000, 295(3): I206-1222.

34. Pillai G, Brown NA, McAllister G, Milligan G, Seabrook GR: Human D2 and D4 dopamine receptors couple through betagamma G-protein subunits to inwardly rectifying $K+$ channels (GIRKI) in a Xenopus oocyte expression system: selective antagonism by L-74I,626 and L-745,870 respectively. Neuropharmacology 1998, 37(8):983-987.
35. Liu YF, Civelli O, Grandy DK, Albert PR: Differential sensitivity of the short and long human dopamine D2 receptor subtypes to protein kinase C. J Neurochem 1992, 59(6):23।I-23 I7.

36. Wang C, Buck DC, Yang R, Macey TA, Neve KA: Dopamine D2 receptor stimulation of mitogen-activated protein kinases mediated by cell type-dependent transactivation of receptor tyrosine kinases. J Neurochem 2005, 93(4):899-909.

37. Roberts DJ, Lin H, Strange PG: Mechanisms of agonist action at D2 dopamine receptors. Mol Pharmacol 2004, 66(6): I573-1579.

38. Usiello A, Baik JH, Rouge-Pont F, Picetti R, Dierich A, LeMeur M, Piazza PV, Borrelli $E$ : Distinct functions of the two isoforms of dopamine D2 receptors. Nature 2000, 408(6809): 199-203.

39. Banihashemi B, Albert PR: Dopamine-D2S receptor inhibition of calcium influx, adenylyl cyclase, and mitogen-activated protein kinase in pituitary cells: distinct Galpha and Gbetagamma requirements. Mol Endocrinol 2002, 16(10):2393-2404.

40. Gay EA, Urban JD, Nichols DE, Oxford GS, Mailman RB: Functional selectivity of D2 receptor ligands in a Chinese hamster ovary hD2L cell line: evidence for induction of ligand-specific receptor states. Mol Pharmacol 2004, 66(I):97-105.

41. Garcia-Jimenez C, Zaballos MA, Santisteban P: DARPP-32 (dopamine and 3',5'-cyclic adenosine monophosphate-regulated neuronal phosphoprotein) is essential for the maintenance of thyroid differentiation. Mol Endocrinol 2005, 19(12):3060-3072.

42. Borta A, Hoglinger GU: Dopamine and adult neurogenesis. J Neurochem 2007, 100(3):587-595.

43. Kotani S, Yamauchi T, Teramoto T, Ogura H: Pharmacological evidence of cholinergic involvement in adult hippocampal neurogenesis in rats. Neuroscience 2006, I 42(2):505-5I4.

44. Mayerhofer A, Kunz L: A non-neuronal cholinergic system of the ovarian follicle. Ann Anat 2005, 187(5-6):52I-528.

45. Mayerhofer A, Kunz L, Krieger A, Proskocil B, Spindel E, Amsterdam A, Dissen GA, Ojeda SR, I W: FSH regulates acetycholine production by ovarian granulosa cells. Reprod Biol Endocrinol 2006, 174(4):37.

46. Basu S, Nagy JA, Pal S, Vasile E, Eckelhoefer IA, Bliss VS, Manseau EJ, Dasgupta PS, Dvorak HF, Mukhopadhyay D: The neurotransmitter dopamine inhibits angiogenesis induced by vascular permeability factor/vascular endothelial growth factor. Nat Med 200I, 7(5):569-574.

47. Lara HE, Dorfman M, Venegas M, Luza SM, Luna SL, Mayerhofer A Guimaraes MA, Rosa ESAA, Ramirez VD: Changes in sympathetic nerve activity of the mammalian ovary during a normal estrous cycle and in polycystic ovary syndrome: Studies on norepinephrine release. Microsc Res Tech 2002, 59(6):495-502.

48. Mani S: Signalling mechanisms in progesterone-neurotransmitter interactions. J Mol Endocrinol 2003, 30(2): |27-137.
Publish with Biomed Central and every scientist can read your work free of charge

"BioMed Central will be the most significant development for disseminating the results of biomedical research in our lifetime. "

Sir Paul Nurse, Cancer Research UK

Your research papers will be:

- available free of charge to the entire biomedical community

- peer reviewed and published immediately upon acceptance

- cited in PubMed and archived on PubMed Central

- yours - you keep the copyright
BioMedcentral 